\title{
Obituary
}

Dr. Emile Roux, For.Mem.R.S.

$\mathrm{B}^{\mathrm{Y}}$ the death on November 3 of Dr. Émile Roux, the director of the Institut Pasteur in Paris, France and the rest of the world have lost a great man of science who was the last and most famous of the assistants and co-workers of Pasteur. Dr. Roux was, by common consent, the most respected figure in the bacteriological world to-day and it will be almost impossible to fill the post which he had so long held in France.

Pierre-Paul-Emile Roux was born on December 17, 1853, at Confolens (dep. Charente), the son of the principal of a college in that small town. Émile went to school at Confolens and finished his early education at Aurillac and Le Puy, where he took his degree of bachelor of sciences. Shortly afterwards he began the study of medicine at Clermont-Ferrand where he first came into contact with Emile Duclaux, who afterwards was to have a great influence on Roux's career. At that time Duclaux was acting as suppléant of the chair of chemistry at Clermont and filled his classroom with students whose imaginations were fired by hearing from Duclaux the wonderful fields which had been opened up for medicine by the researches of Pasteur on fermentations. It was in Duclaux's laboratory that the young Roux carried out his first research in 1873 .

Later Roux went to Paris to complete his medical education, and having done so he entered the military hospital of Val-de-Grâce. The military regime was not altogether to Roux's liking and he attached himself to the Hôtel Dieu, where he was aide-de-clinique from 1873 until 1877. By that time his old Clermont teacher Duclaux had been transferred to Paris as professor of meteorology in the Institut Agronomique and also lectured at the Sorbonne. Duclaux also worked in Pasteur's famous laboratory at the École Normale Supérieure in the Rue d'Ulm. Roux became préparateur to Duclaux and attracted the attention of Pasteur, with whose subsequent career he was closely united first as assistant and then as sousdirecteur adjoint of Pasteur's laboratory, being junior to Charles Chamberland, who was Pasteur's chief assistant.

Chamberland and Roux played a leading part in the researches of Pasteur on anthrax (1879-1882) and they were honourably designated by the master as his collaborators and not merely as assistants. Chamberland and Roux were also the principal workers in the famous series of researches on hydrophobia which Pasteur in their joint names published in 1881-1886 and which led to the discovery of the prophylaxis by the attenuated virus of rabies. In 1883 Roux was sent by Pasteur to Egypt to study cholera, the cause of which was unknown at that time.

When the Institut Pasteur was opened in the Rue Dutot in Paris in 1888, Roux was appointed chef de service (1888-1897), sous-directeur (1897-
1904), and on the death of the Directeur Duclaux in 1904, Roux became director of the Institut Pasteur and he occupied this important position until his death twenty-nine years later.

From the time of the opening of the Institut Pasteur, Roux published many important researches in his own name alone but more frequently with his assistants. To this period belong his papers on bacteriological technique, the passage of the virus of rabies along the nerves, and the pathology of experimental lockjaw. In association with Alexandre Yersin, Roux carried out extensive researches on the nature of diphtheria (1888-1890), and they made the important discovery of the existence of diphtheria toxin. These researches of Roux and Yersin aroused great interest and they directly led to the discovery by Emil Behring of diphtheria antitoxin, which discovery was announced on December 4, 1890. Roux at once saw the fundamental importance of Behring's discovery and set to work to devise a suitable technique for the purpose of producing antitoxin on a large scale. He was the first to employ the horse as a suitable animal for antitoxin production, and his methods are in use to-day. With the antitoxin he prepared he carried out a long series of observations on children treated with antitoxin. The lecture on his results at the eighth International Congress of Hygiene and Demography in Budapest in September 1894 aroused world-wide interest and inaugurated a new era in the therapeutics of diphtheria.

In addition to his research work, Roux founded and conducted a course on microbiology at the Institut Pasteur, and during his lifetime taught something like three thousand students of all nations. In this course he revealed himself as a teacher of the first rank and held his audiences spellbound by his eloquence.

In 1903-1906 Roux, in conjunction with Metchnikoff, carried out fundamental experiments on syphilis and showed that this mysterious disease can be communicated to anthropoid apes.

From 1906 Roux's energies were almost completely absorbed in the direction of his Institute. For many years he was a sickly man and suffered from some malady believed, probably incorrectly, to have been some chronic form of tuberculosis. He was thin and emaciated and appeared to suffer from exposure to cold, for he was rarely seen, even in summer, without his long pelerine, with a woollen muffler round his neck. All the cold in the world could, however, not destroy the indomitable spirit of this great Frenchman, who was game to the end and from whose worn-out body radiated the enthusiasm of youth.

Roux was an abrupt man in his intercourse with strangers, but everyone who came for long into his atmosphere left it with a lifelong feeling of reverence and devotion. He was devoid of vanity and as a character sound to the core. Throughout his life he was an ardent student of science. His 
salary as director of the Institut Pasteur was trifling, for he had little use for it. He was a bachelor and lived in two small rooms in the hospital of the Pasteur Institute where he was devotedly cared for and nursed by one of the sisters.

All his old friends and early contemporaries were dead and when his last old colleague, Calmette, died, on October 29, this broke Roux up, and he survived only another four days and passed away on November 3 in his eightieth year.

Roux was elected a foreign member of the Royal Society in 1913, and was awarded the Copley medal of the Society. He also held the much coveted 'Grand-croix de la legion d'honneur'. Roux was held in such esteem in France that he was awarded an imposing national funeral which, personally, it is certain he would not have desired. His remains are to be finally deposited in the garden of the Institut Pasteur which he had loved so much.

W. B.

\section{Prof. W. Mielck}

Prof. W. MLelck, director of the Biological Station at Heligoland, who died on October 5, was educated at Hamburg, Göttingen and Kiel, and carried out his first research work at Kiel under Prof. K. Brandt. In 1907 he was appointed to the staff of the Biological Station at Heligoland, with which institution his life-work was bound up. From 1910 he was associated with the late Prof. Heincke in fishery investigations, especially in relation to the plaice and the over-fishing problem, carrying on, however, at the same time the plankton researches which he had commenced at Kiel.

During the War, Mielck's duties kept him in Heligoland, where he not only continued such research work as was possible, but also organised a successful local fishery. This direct experience gave him much interest and insight into the effect of the War on the stocks of fish, a question which was energetically studied by the Heligoland staff in the ensuing years. He succeeded Prof. Heincke as director in 1921 and threw his whole energy into the rebuilding and reorganisation of the Biological Station, which has become the most important institution in Germany for marine biological research.

When Germany rejoined the International Council for the Exploration of the Sea in 1926 , Mielck was appointed one of the two delegates from that country, and played an important part in the organisation and direction of his country's share in the international investigations. In 1928 he succeeded Mr. Borley as chairman of the Southern North Sea Committee, and carried out the duties attached to this post in a manner which at once earned for him the respect and support of his foreign colleagues. It was characteristic of Mielck's thoroughness and strong sense of duty that he set himself to master the English language in order to preside more effectively over his Committee.

Mielck was a hard worker and found time to carry out intensive researches on herring larvæ in addition to his onerous official duties as director of the Biological Station. His premature and sudden death at the age of fifty-four years has robbed Germany of a first-class worker, the International Council of a valued collaborator, and his coworkers of a staunch friend. His British colleagues on the International Council, of whom the present writer was one, regarded Mielck with admiration and affection, and deeply mourn his loss.

\section{E. S. R.}

WE regret to announce the following deaths :

Dr. G. S. Coleman, director of the Department of Municipal Engineering in the College of Technology (University of Manchester), on November 7.

Mr. R. B. Mellon, who, with his brother, Mr. Andrew Mellon, formerly American Ambassador in London, founded the Mellon Institute of Industrial Research, Pittsburgh, on December 2, aged seventy-five years.

\section{News and Views}

\section{Heavy Hydrogen and Heavy Water}

IN connexion with the forthcoming discussion on December 14 at the Royal Society on "Heavy Hydrogen" and the letter by A. and L. Farkas in this issue of NatuRe, p. 894, it is interesting to have the results of additional experiments with heavy water, containing the hydrogen isotope $\mathrm{H}^{2}$ (isohydrogen or deuterium) reported from the United States (Harkins and Doede ; Barnes ; H. S. Taylor, Caley and Eyring; Selwood and Frost; G. N. Lewis and Macdonald; Olson and Maroney : J. Amer. Chem. Soc., Oct.-Nov.). An apparatus for the separation by electrolysis is described in which an alkaline solution is electrolysed between concentric nickel tubes. The solubilities of a few salts are found to be distinctly less in heavy water than in ordinary distilled water, the difference in the case of barium chloride being 19 per cent. Various physical properties such as density, refractive index, viscosity, surface tension, dielectric constant and magnetic susceptibility have been measured with specimens of heavy water containing $31,63.5$ and 92 per cent of the hydrogen in the form of $\mathrm{H}^{2}$. Previous results are confirmed in general, and some additional information obtained. The viscosity is larger, and the dielectric constant smaller, than for ordinary water. The molar magnetic susceptibilities are equal. An advance report through Science Service, Washington, states that heavy water is lethal to fish, tadpoles and worms, but paramecia resisted it for twenty-four hours. 